Studia Judaica 20 (2017), nr 1 (39), s. 47-75

doi:10.4467/24500100STJ.17.003.7729

Scott Ury

\title{
Strach i nienawiść na ulicach Warszawy: Przemoc, rewolucja i antysemityzm polityczny*
}

\author{
FEAR AND LOATHING ON THE STREETS OF WARSAW: \\ VIOLENCE, REVOLUTION, AND THE RISE OF POLITICAL ANTISEMITISM
}

\begin{abstract}
Focusing on the period surrounding the revolution of 1905 in Warsaw, this article examines the relationship between four different types of violenceurban, revolutionary, governmental, and interethnic - that repeatedly influenced the lives of many of the city's 775,000 residents. As part of this contextual approach to studying and understanding intergroup violence in an urban setting, the author maintains that while the causal relationship between social, political, and interethnic violence in Warsaw was never linear, its influence was very often reciprocal and incremental, if not, at times, exponential. This synchronic analysis of the different types of violence is critical for understanding the rising tensions between Poles and Jews in turn-of-the-century Warsaw as well as Jewish interpretations of these developments. In addition to shedding much light on key social and political developments during this period, this contextual analysis of various types of intergroup conflict in one city also challenges the two predominant scholarly paradigms for studying moments of anti-Jewish violence: the longue durée school of antisemitism and the theme of Polish-Jewish coexistence.
\end{abstract}

Keywords: Revolution of 1905, fear, Jews in Warsaw, revolution in Warsaw, violence, antisemitism.

Słowa kluczowe: rewolucja 1905, strach, Żydzi w Warszawie, rewolucja w Warszawie, przemoc, antysemityzm.

Pracę nad tym artykułem umożliwiła mi szczodra dotacja przyznana przez Fundację Naukową Izraela (Israel Science Foundation (ISF), grant nr 361/12). Chciałbym podziękować anonimowym recenzentom i redaktorom pisma "Studia Judaica” za niezmiernie przydatne komentarze oraz porady w odniesieniu do wcześniejszych wersji tego artykułu. Niektóre ze źródeł przywołanych w niniejszym studium pojawiły się także w mojej książce: Scott Ury, Barricades and Banners: The Revolution of 1905 and the Transformation of Warsaw Jewry, Stanford 2012. Chciałbym również podziękować Ani Switzer za staranny przekład tego artykułu. 


\section{Wprowadzenie}

Na przełomie XIX i XX w. wielu spośród 775 tys. oficjalnie zarejestrowanych mieszkańców Warszawy wiodło życie pełne strachu, w ciągłym poczuciu zagrożenia przemocą. Ówczesną sytuację miasta można określić jako złożoną, na co składały się procesy urbanizacyjne, które w II połowie XIX w. przybrały zawrotne tempo, natężenie działalności rewolucyjnej ze strony licznych organizacji, wzrost napięć etnicznych pomiędzy Polakami a Żydami i wreszcie - kolejne próby podejmowane przez władze starające się uzyskać kontrolę nad, jak się wydawało, niemającą końca falą niepokojów społecznych. Stan rzeczy dodatkowo pogarszały odrębne, lecz w pewien sposób powiązane ze sobą konflikty, które znacząco wpłynęły nie tylko na atmosferę okresu rewolucji 1905 r., ale również na charakter społeczności żydowskiej i polskiej, ich poglądy polityczne oraz wzajemne relacje w późniejszych latach $\mathrm{XX}$ w. ${ }^{1}$

Można przypuszczać, że wiodący historycy, m.in. Feliks Tych, Theodore Weeks czy Joshua Zimmerman, postrzegali gwałtowne wydarzenia między rokiem 1904 a 1907 jako serię kolejnych wypadków o charakterze przede wszystkim politycznym, które nastąpiły jeden po drugim i które w bezpośredni sposób z siebie wynikały. Tymczasem - moim zdaniem społeczne, polityczne i indywidualne doświadczenie przemocy na ulicach Warszawy (a także w sąsiednich miastach i miasteczkach) miało o wiele bardziej złożony charakter. ${ }^{2} \mathrm{~W}$ związku z tym chciałbym zaproponować spojrzenie na opisywaną rzeczywistość z innej perspektywy. Artykuł ten jest dla mnie okazją do omówienia różnych rodzajów przemocy, do których dochodziło w Warszawie - miejskiej, rewolucyjnej, ze strony obozu rządzącego i międzyetnicznej - jako zbioru odrębnych, lecz jednak powiązanych ze sobą zjawisk społecznych i politycznych. Wszystkie wyżej wymienione formy przemocy różnią się między sobą zarówno pod względem zaangażowanych w nie aktorów społecznych, cech charakterystycznych oraz motywów, jak i samym przebiegiem wydarzeń. Niemniej jednak stoję na stanowisku, że aby w pełni zrozumieć istotę warszawskiej społeczności

${ }^{1}$ Więcej informacji na ten temat - zob.: tamże.

2 Zob. np. Robert E. Blobaum, Rewolucja: Russian Poland, 1904-1907, Ithaca 1995; Feliks Tych, Stanisław Kalabiński, Czwarte powstanie czy pierwsza rewolucja. Lata 1905-1907 na ziemiach polskich, Warszawa 1969; Joshua D. Zimmerman, Poles, Jews, and the Politics of Nationality: The Bund and the Polish Socialist Party in Late Tsarist Russia, 1892-1914, Madison 2004, s. 191-226; Ury, Barricades and Banners...; Theodore R. Weeks, From Assimilation to Antisemitism: The „Jewish Question” in Poland, 1850-1914, DeKalb 2006, s. 129-163. 
miejskiej, ówczesną politykę i konflikty między grupami etnicznymi, do których doszło na początku XX w., należy przeanalizować wzajemne oddziaływania i wpływy różnych rodzajów przemocy. ${ }^{3} \mathrm{~W}$ ramach przedstawionego w tym artykule synchronicznego podejścia do badań i rozumienia przemocy między grupami utrzymuję, że pomimo braku bezpośredniego związku przyczynowego pomiędzy przemocą społeczną, polityczną i na tle etnicznym można zauważyć między tymi zjawiskami pewne zależności ${ }^{4}$. Bardzo często polegały one na wzajemnym oddziaływaniu, które na ogół przebiegało stopniowo, czasami jednak wpływ ten przybierał gwałtowne formy. Warszawa przy tym stanowiła podatny grunt dla różnych aktów przemocy; im częściej do nich dochodziło, tym bardziej życie w mieście wydawało się ryzykowne. Budziło to z kolei coraz większe zaniepokojenie wielu mieszkańców, obserwatorów życia społecznego i urzędników. Wobec postępującego chaosu obawy dotyczyły także przyszłego kształtu społeczności miasta i sytuacji Warszawy u progu XX w. ${ }^{5}$

Metodologia badań nad przemocą wobec Żydów na ziemiach polskich i na pozostałym obszarze Europy Środkowo-Wschodniej powinna w szczególności uwzględniać kontekstowe i synchroniczne podejście do konfliktu pomiędzy grupami w otoczeniu miejskim. Kontekstowe ujęcie problemu przemocy miejskiej jest przede wszystkim wyzwaniem dla dwóch dominujących paradygmatów naukowych w zakresie badania i rozumienia agresji wobec Żydów oraz stosunków polsko-żydowskich. Pierwsza szkoła myślenia, która rozwinęła się jednocześnie z dyscypliną historii żydowskiej, postrzega wystąpienia antyżydowskie i pogromy w Imperium Rosyjskim

${ }^{3}$ Argument ten przedstawiony jest dość przekonująco w: Charters Wynn, Workers, Strikes, and Pogroms: The Donbass-Dnepr Bend in Late Imperial Russia, 1870-1905, Princeton 1992, s. 108-109, 127, 198-199, 225-226, 257; Darius Staliūnas, Enemies for a Day: Antisemitism and Anti-Jewish Violence in Lithuania under the Tsars, Budapest 2015; jak również w: Michael F. Hamm, Kiev: A Portrait, 1800-1917, Princeton 1993, s. 205-207; Joan Neuberger, Hooliganism: Crime, Culture, and Power in St. Petersburg, 1900-1914, Berkeley 1993, s. 71-110.

${ }^{4} \mathrm{Na}$ pewne powiązania wskazuje Artur Markowski, Anti-Jewish Pogroms in the Kingdom of Poland, „Polin” 27 (2014), s. 249-250.

${ }_{5}$ Zob. omówienie przemocy międzyetnicznej w środowisku miejskim w: Veena Das, Introduction: Communities, Riots, Survivors - The South Asian Experience, [w:] Mirrors of Violence: Communities, Riots and Survivors in South Asia, red. Veena Das, Oxford 1990, s. 1-36; John D. Klier, Russians, Jews and the Pogroms of 1881-1882, Cambridge 2011; Stanley J. Tambiah, Leveling Crowds: Ethnonationalist Conflicts and Collective Violence in South Asia, Berkeley 1997; Richard C. Wade, Violence in the Cities: A Historical Overview, [w:] Cities under Siege: An Anatomy of the Ghetto Riots, 1964-1968, red. David Boesel, Peter H. Rossi, New York-London 1971, s. 277-296; Robert Weinberg, The Revolution of 1905 in Odessa: Blood on the Steps, Bloomington 1993. 
(i innych miejscach) jako zjawiska nierozerwalnie połączone z dziesiątkami wieków napięć, a także retoryki i działań skierowanych przeciwko Żydom, których to początki wiązać należy z pojawieniem się chrześcijaństwa lub może nawet z epoką wcześniejszą. Orędownikami takiej perspektywy byli najważniejsi historycy żydowscy z Szymonem Dubnowem na czele, a jej kontynuację znaleźć można w pracach uznanych autorytetów badań nad antysemityzmem, jak np. Robert Wistrich. Podejście do antysemityzmu zwane szkołą longue durée (długiego trwania) bardzo często ukazuje antysemityzm jako odwieczną, potencjalnie a priori zdeterminowaną strukturę historyczną, czasem nawet o niezmiennym charakterze ${ }^{6}$. Ten typ myślenia często prowadzi do umniejszenia znaczenia czynników i podmiotów lokalnych.

Paradoksalnie, kontekstowa oraz synchroniczna analiza miejskich niepokojów, konfliktów etnicznych i przemocy antyżydowskiej podważa ustalenia również tych badaczy życia społecznego, którzy utrzymują (zarówno w przeszłości, jak i współcześnie), że względnie niski poziom przemocy wobec Żydów warszawskich w początkach XX w. należy odczytać jako oznakę zasadniczo dobrych stosunków międzysąsiedzkich, a nawet dowód, że był to okres prawdziwie wspólnego życia Polaków i Żydów. ${ }^{7}$ Perspektywa ta jest również próbą przedstawienia przemocy antyżydowskiej w Imperium Rosyjskim jako odrębnego czy wyjątkowego problemu rosyjskiego bądź ukraińskiego, z zasady odmiennego od zjawisk zachodzących w społeczeństwie polskim. Takie ujęcie stwarza z kolei ryzyko wypaczenia oraz błędnej interpretacji poziomu napięcia i przemocy w Warszawie oraz wpływu tych zjawisk na społeczność żydowską.

W zakończeniu tego fragmentu rozważań należy dodać, że synchroniczne oraz kontekstowe ujęcie różnych rodzajów przemocy w Warszawie na początku XX w. ukazuje słaby stan tkanki miejskiej i szczególną

${ }^{6}$ Zob.: Simon Dubnow, The Moral of Stormy Days, [w:] tenże, Nationalism and History: Essays on Old and New Judaism, red. Koppel S. Pinson, Philadelphia 1958, s. 202; Robert S. Wistrich, A Lethal Obsession: Anti-Semitism from Antiquity to the Global Jihad, New York 2010, s. 17-21.

${ }^{7}$ Zob. historyczny aspekt tych zagadnień: Weeks, From Assimilation to Antisemitism..., s. 74-85. Więcej informacji na temat tego zjawiska w: Ezra Mendelsohn, Interwar Poland: Good for the Jews, or Bad for the Jews?, [w:] The Jews in Poland, red. Chimen Abramsky, Maciej Jachimczyk, Antony Polonsky, Oxford 1986, s. 130-139; Scott Ury, Who, What, When, Where, and Why is Polish Jewry? Envisioning, Constructing and Possessing Polish Jewry, „Jewish Social Studies” 6 (2000), nr 3, s. 212-213. Współczesne ujęcie postaw tego typu w: Nahum Sokolow, Undated Draft of an Article about the Pogrom in Warsaw, Dec., 1881, [w:] Ela Bauer, Between Poles and Jews: The Development of Nahum Sokolow's Political Thought, Jerusalem 2005, s. 159-161. 
niepewność egzystencji, jaką odczuwali Żydzi, Polacy i inni warszawiacy. Dlatego też w poniższej analizie nakładających się na siebie obszarów przemocy w Warszawie przełomu wieków przedstawione zostaną te problemy, które zarówno szkoła długiego trwania antysemityzmu, jak i interpretacje cechujące się pozytywnym (a nawet wykazującym skłonności do usprawiedliwiania napięć) ujmowaniem relacji polsko-żydowskich niejednokrotnie pomijają, powodując z kolei błędną ocenę wpływu czynników lokalnych i roli aktorów historycznych ${ }^{8}$. Jeśli spojrzeć na inne przypadki analizy na gruncie determinizmu historycznego lub politycznie motywowanych paradygmatów naukowych, można z łatwością dostrzec pewne podobieństwa. Zwolennicy pierwszego lub drugiego sposobu interpretacji antysemityzmu i stosunków polsko-żydowskich często stają się do tego stopnia przekonani o słuszności własnych założeń epistemologicznych i ram analitycznych, że błędnie oceniają wpływ czynników lokalnych, a także samą możliwość istnienia zależności historycznych między opisywanymi zjawiskami.

\section{Przemoc miejska}

W II połowie XIX i na początku XX w. Warszawa, podobnie jak wiele innych ośrodków miejskich rozległego obszaru Europy ŚrodkowoWschodniej, odnotowała gwałtowny wzrost liczby ludności. Według różnych danych statystycznych ogólna populacja miasta wzrosła z ok. 81 tys. w 1816 r. do ok. 223 tys. osób w 1864 r. W 1897 r. miasto liczyło ok. 625 tys. mieszkańców, w 1914 r. - ponad 885 tys. W tym samym czasie liczba zarejestrowanej ludności żydowskiej miasta wzrosła ponad dwudziestokrotnie: z 15,6 tys. w 1816 r. do 72,8 tys. osób w 1864 r. oraz z 210,5 tys. w 1897 r. do 337 tys. mieszkańców w 1914 r. W wyniku tych zmian względny odsetek ludności żydowskiej w mieście podwoił się: w 1816 r. było to $19 \%$, a w 1914 r. - 38\% mieszkańców Warszawy ${ }^{9}$. Chociaż liczby te należy traktować jako dane szacunkowe, pozwalają nam one jednak

${ }^{8}$ O tej i podobnych kwestiach dość przekonująco pisze Brian Porter, When Nationalism Began to Hate: Imagining Modern Politics in Nineteenth-Century Poland, New York 2000; a także Weeks, From Assimilation to Antisemitism... Więcej informacji na ten temat w: Joanna B. Michlic, Poland's Threatening Other: The Image of the Jew from 1880 to the Present, Lincoln 2006 (wyd. pol.: Joanna B. Michlic, Obcy jako zagrożenie. Obraz Żyda w Polsce od roku 1880 do czasów obecnych, Warszawa 2015 - przyp. thum.).

${ }^{9}$ Zob.: Stephen D. Corrsin, Warsaw before the First World War: Poles and Jews in the Third City of the Russian Empire, 1880-1914, Boulder 1989; tenże, Aspects of Population Change and of Acculturation in Jewish Warsaw at the End of the Nineteenth Century: The Censuses of 1882 and 1897, [w:] The Jews in Warsaw: A History, red. Władysław T. Bartosze- 
nakreślić szerszy obraz wzrostu demograficznego w Warszawie, a także zmieniającego się składu etnicznego miasta w czasie ponad stu lat - od kongresu wiedeńskiego do wybuchu I wojny światowej.

Znaczny odsetek opisanej tu ekspansji demograficznej z lat 1816-1914 był wynikiem przyrostu naturalnego. Oprócz tego dużą część gwałtownego wzrostu populacji spowodowało pojawienie się dziesiątków tysięcy młodych ludzi, którzy przybyli do Warszawy z okolicznych miast, miasteczek i wiosek ${ }^{10}$. Podobnie jak miliony imigrantów, którzy zamieszkali także w innych szybko rozwijających się miastach Imperium Rosyjskiego, wielu z nowo przybyłych młodych mężczyzn i kobiet przeniosło się do Warszawy w poszukiwaniu lepszych szans ekonomicznych, uczestnictwa w kulturze i wreszcie - by rozpocząć nowy etap życia w czasach pełnych obietnic i nadziei ${ }^{11}$. Przytoczone dane statystyczne obrazują dwa podstawowe wydarzenia, do których doszło w Warszawie w ciągu długiego XIX w., a które są niezbędne dla zrozumienia omawianych tu zjawisk: całkowity przyrost liczby ludności (żydowskiej i pozostałej) na zupełnie wyjątkową skalę oraz rosnący odsetek młodych przybyszów obecnych w mieście. W podobnym kontekście Brower zauważył, że owe znaczące zmiany demograficzne przeobraziły Warszawę i wiele innych miast w Rosji przełomu wieków „w wielkie drzwi obrotowe, przez które przeszła znaczna część ludności” ${ }^{12}$. Ponadto - w wyniku transformacji z przyczółka caratu w duże miasto - Warszawa przekształciła się w ciągu prawie dwóch pokoleń w ośrodek zamieszkany przez ogromną, chaotyczną i niełatwą do opanowania rzeszę nowych przybyszów ${ }^{13}$.

Połączenie szybkiego wzrostu demograficznego, powszechnej anonimowości oraz rosnącego poczucia niepokoju pomogło utorować drogę

wski, Antony Polonsky, Cambridge 1991, s. 214; Piotr Wróbel, Jewish Warsaw before the First World War, [w:] The Jews in Warsaw..., s. 255.

${ }_{10}$ Analiza wpływu migracji wewnętrznych na sprawy związane ze statystyką ludności żydowskiej w: Shaul Stampfer, Patterns of Internal Jewish Migration in the Russian Empire, [w:] Jews and Jewish Life in Russia and the Soviet Union, red. Yaacov Ro'i, Ilford 1995, s. 28-47.

${ }^{11}$ Więcej na temat migracji i rozwoju miast w całym Imperium Rosyjskim zob.: Joseph Bradley, Muzhik and Muscovite: Urbanization in Late Imperial Russia, Berkeley 1985; Hamm, Kiev..., s. 18-54; Diane P. Koenker, Moscow Workers and the 1917 Revolution, Princeton 1981, s. 43-93; Wynn, Workers, Strikes, and Pogroms..., s. 67-94.

${ }_{12}$ Daniel R. Brower, Urban Revolution in Late Imperial Russia, [w:] The City in Late Imperial Russia, red. Michael F. Hamm, Bloomington 1986, s. 327.

${ }_{13} \mathrm{Na}$ temat nowoczesności, życia miejskiego i anonimowości zob.: Georg Simmel, The Stranger, [w:] Georg Simmel on Individuality and Social Forms, red. Donald N. Levine, Chicago 1971, s. 143-149; tenże, The Metropolis and Mental Life, [w:] Georg Simmel on Individuality..., s. 324-339; Walter Benjamin, On Some Motifs in Baudelaire, [w:] tenże, Illuminations: Essays and Reflections, red. i wstęp Hannah Arendt, tłum. Harry Zohn, New York 2007, s. 166-176. Zob. także: Peter Fritzsche, Reading Berlin 1900, Cambridge 1996. 
fali przemocy, która wkrótce stała się przekleństwem miasta i wielu jego mieszkańców, zarówno Żydów, jak i pozostałych nacji ${ }^{14}$. Zjawiska związane z rosnącą falą przestępczości miejskiej, codziennymi aktami przemocy, do których dochodziło w sferze publicznej, oraz zapowiedziami nadchodzącej anarchii społecznej i politycznej szczególnie starannie odnotowywała prasa codzienna, ukazująca się m.in. w języku polskim, jidysz i hebrajskim ${ }^{15}$. Gazety chętnie opisywały sensacyjne i drastyczne historie przestępstw oraz przemocy, ponieważ pomagało to zwiększyć poziom czytelnictwa i przychodów. W rezultacie lokalne dzienniki wielokrotnie przedstawiały obraz miasta jako nowoczesnej metropolii na skraju całkowitego załamania i destrukcji. W istocie - wiele z nowo utworzonych warszawskich gazet wydawanych w języku jidysz, takich jak „Der Weg” [Droga], „Unzer Leben” [Nasze Życie] i „Jidiszes Tageblat” [Dziennik Żydowski], było tak pochłoniętych zjawiskami przestępczości i przemocy, że regularnie, niemal codziennie, ukazywały się tam artykuły z tak sugestywnymi podtytułami, jak np.: „zbrodnie”, „zamieszki”, „ataki”, „morderstwa” lub zwyczajnie „przemoc" ${ }^{\prime 6}$. Niedawni przybysze, kobiety i osoby odwiedzające miasto na krótszy czas byli wielokrotnie przedstawiani jako potencjalne ofiary (lub ludzie, których można łatwo wykorzystać lub oszukać) owych pozornie przypadkowych, często nieprzewidywalnych i potencjalnie bezustannych aktów przemocy. Nowoczesne miasto, z właściwą mu wielkością, tendencjami do ciągłych zmian i anonimowością, stanowiło podatny grunt dla rozwoju agresji ${ }^{17}$.

${ }^{14}$ Zob. Neuberger, Hooliganism ..., s. 4: „Chuligaństwo powstało i rozwijało się w punkcie przecięcia zmian społecznych i kulturowych, które miały miejsce na przełomie XIX i XX w. Procesy te powiązane były z szybkim postępem procesów urbanizacyjnych, industrializacją oraz zmianami demograficznymi. Był to też moment powstania społeczeństw bardziej demokratycznych, otwartych; równocześnie nadchodziła epoka rewolucji”. Zob. również: tamże, s. 109. Więcej informacji na temat urbanizacji i przemocy w tym i podobnych kontekstach w: Blobaum, Rewolucja ..., s. 93; Klier, Russians, Jews and the Pogroms of 1881-1882..., s. 58; Wade, Violence in the Cities..., s. 277-278; Weinberg, The Revolution of 1905 in Odessa ..., s. 15; Wynn, Workers, Strikes, and Pogroms..., s. 86-89, 257.

${ }^{15}$ Neuberger, Hooliganism..., s. 15. Więcej na temat kluczowej roli prasy brukowej w tym okresie zob.: tamże, s. 19, 58; Fritzsche, Reading Berlin 1900... Zob. także Roshanna P. Sylvester, Tales of Old Odessa: Crime and Civility in a City of Thieves, DeKalb 2005.

${ }^{16}$ Np. tytuły stałych rubryk w „Jidiszes Tageblat”: „Mordestwa i napaści” oraz „Napaści i rabunki” - zob. „Jidiszes Tageblat” (23 lipca / 5 sierpnia 1906), nr 57, s. 3; „Jidiszes Tageblat” (27 sierpnia / 9 września 1906), nr 87, s. 4. Zob. inne przykłady: „Di Naje Cajtung” (14/27 sierpnia 1906), nr 12, s. 1; „Unzer Leben” (5/18 czerwca 1907), nr 87, s. 3; „Der Telegraf” (21 kwietnia / 4 maja 1906), nr 86, s. 2; „Der Weg” (4/17 sierpnia 1905), nr 4, s. 3.

${ }_{17}$ Zob. więcej informacji na temat losu Żydów z marginesu społecznego w mieście: Ury, Barricades and Banners..., s. 61-76. 
Należy również zauważyć, że chociaż dla prasy codziennej podkreślanie i wyolbrzymianie aktów przemocy z pewnością było zajęciem intratnym, nie umniejsza to rzeczywistego wpływu tego rodzaju reportażu na wizerunek miasta. Przekładało się to z kolei na doświadczenie życia codziennego setek tysięcy mieszkańców Warszawy i innych miast Europy Środkowo-Wschodniej. W uwagach na temat roli, jaką odegrała prasa codzienna w tworzeniu „klimatu strachu” w Petersburgu i innych miastach w tym samym czasie, Neuberger odnotowała, że:

Wzrost przestępczości był powszechnie zauważany i omawiany, co wydawało się przyczyniać do ogólnego nastroju paniki [...]. Zarówno liczba chuligańskich wybryków, jak i bezczelność awanturników sięgnęły nowych szczytów. Do rozbojów dochodziło z przerażającą regularnością, a przyczyny ich występowania były również niezrozumiałe ${ }^{18}$.

Ponadto w miarę rozwoju Warszawy zarówno nowi i dawni mieszkańcy, jak też przyjezdni w coraz większym stopniu traktowali gazety jako podstawowe źródło wiadomości, informacji i wskazówek dotyczących różnych aspektów życia miejskiego, których nie mogliby poznać i zrozumieć w inny sposób. Pod tym i innymi względami dzienniki nie tylko najskuteczniej pomagały zorientować się w zawiłościach nowoczesnej metropolii, ale też znakomicie służyły jako narzędzie pomocne w poznaniu, interpretacji i zrozumieniu nowych zjawisk życia miejskiego ${ }^{19}$. Taka funkcja zapewniała gazetom niezmiernie ważną rolę socjologiczną, zainteresowanie bowiem dziennikarzy problemem przestępczości i przemocy (które graniczyło z obsesją) przekładało się na doświadczenie życia w społeczności miejskiej dla dziesiątków tysięcy czytelników i mieszkańców miasta.

Istnieje ogromna liczba doniesień prasowych na temat przestępczości i przemocy w miastach w omawianym czasie. Poniższe przykłady z nowo założonej gazety codziennej ,Jidiszes Tageblat” dobrze ilustrują nowy styl reportażu, często przedstawiający Warszawę jako miejsce ogarnięte falą przemocy, która zdawała się zagrażać każdemu odwiedzającemu tę metropolię, każdemu mieszkańcowi polskiej stolicy czy wreszcie każdemu czytelnikowi. W ten sposób nie tylko informowano czytelnika o konkretnych wydarzeniach, ale też tworzono portret miasta znajdującego się na skraju całkowitego załamania. Nowoczesne miasto wielokrotnie utożsamiano

${ }_{18}$ Neuberger, Hooliganism..., s. 82, 78-79. Zob. także Wynn, Workers, Strikes, and Pogroms..., s. 89-91, 99-100.

19 Zob. Fritzsche, Reading Berlin 1900..., s. 16-20. 
z licznymi obawami, w rzeczywistości dotyczącymi zjawisk o znacznie większej skali, jak np. pytania o charakter współczesnego społeczeństwa. W prezentowanym ujęciu Warszawa miała stanowić ucieleśnienie owych niepokojów:

Wczoraj o czternastej, na rogu Ciepłej i Twardej, dwóch złodziei zagrodziło drogę Izraelowi Rindfleiszowi, dwudziestosiedmioletniemu mieszkańcowi Nowogrodu (?). Zagrozili mu rewolwerami i zażądali pieniędzy, ale Rindfleisz stanął do walki. Napastnicy uderzyli go mocno w twarz, wybijając mu oko, i zabrali mu zegarek ${ }^{20}$.

Wczoraj o jedenastej w nocy opodal ulicy Gęsiej kilku mężczyzn napadło dwudziestoletniego piekarza, Mordechaja Bergazingera, i pobiło go kijami; jeden z nich ugodził ofiarę nożem w klatkę piersiową, po czym wszyscy napastnicy zbiegli ${ }^{21}$.

Za sprawą wielokrotnego powtarzania tego rodzaju doniesień ostatecznie doszło do pewnej normalizacji (a także, potencjalnie, uzasadnienia) fali przestępczości i rozgardiaszu. Niemniej jednak dla wielu mieszkańców miasta - Żydów, Polaków i pozostałych grup - widmo szalonej, niekontrolowanej i przypadkowej przemocy nadal pozostało źródłem stałego i wyniszczającego lęku oraz niepokoju ${ }^{22}$. Po raz kolejny wydawało się, że Warszawa jest miastem, w którym nikt nie może czuć się bezpieczny, gdzie miało się wrażenie, iż przestępczość i przemoc wymykają się spod kontroli, a życie w mieście staje się coraz bardziej niepewne i ryzykowne. Następujący fragment artykułu z 1906 r., pochodzący z nowego, wydawanego w języku hebrajskim dziennika „Ha-Jom” [Dzień], obrazuje pewien typ reportażu, który wielokrotnie ukazywał Warszawę jako miejsce pełne zagrożeń i okrucieństwa, gdzie każdemu grozi zupełnie nieprzewidywalna przemoc, całkowicie pozostająca - wydawałoby się - poza wszelkimi ograniczeniami:

Incydent, do którego doszło na rogu ulic Chłodnej i Białej wczoraj wieczorem i o którym pisaliśmy w ostatnim numerze naszej gazety, pochłonął wiele ofiar. Właściciel baru Garros został zamordowany w swoim lokalu na oczach żony, pracowników i innych osób. Sprawcy uciekli ulicą Białą. Tam wpadli na patrol składający się z jednego policjanta i dwóch żołnierzy. Cała trójka próbowała ich złapać [...]. Napastnicy otworzyli ogień i postrzelili wszystkich trzech członków patrolu.

20 „Jidiszes Tageblat” (11/24 stycznia 1907), nr 10, s. 3.

21 „Jidiszes Tageblat” (20 czerwca / 3 lipca 1907), nr 143, s. 3.

${ }^{22}$ Warto odnotować uwagi Browera na temat sprzeczności między przestępczością w miastach a ówczesnym ideałem życia miejskiego - zob. Daniel Brower, The Russian City between Tradition and Modernity, 1850-1900, Berkeley 1990, s. 218-221. Zob. także Abraham Ascher, The Revolution of 1905, t. 2: Authority Restored, Stanford 1992, s. 7, 146, 161. 
Wkrótce przybyły dodatkowe siły z tego terenu i zaczęto sprawdzać innych ludzi, z których wielu zostało pobitych kolbami albo ugodzonych bagnetami. Pierwszej pomocy udzielono w sumie dziesięciu osobom. Wśród nich byli: Ruben Agorek (siedemnaście lat), Avram Bleinberg (dwadzieścia cztery lata), Bunem Rosenblum (dwadzieścia siedem lat), Szlomo Szary (trzydzieści pięć lat), Mosze Kalender (dwadzieścia osiem lat) i Avram Finkelstein (dwadzieścia lat) ${ }^{23}$.

\section{Przemoc rewolucyjna}

Wzrost aktywności rewolucyjnej w Warszawie i sąsiednich miastach, szczególnie w Łodzi, dodatkowo pogarszał nastroje społeczne, którym towarzyszyło wszechobecne widmo przemocy miejskiej i coraz mniejsze poczucie bezpieczeństwa ${ }^{24}$. Zarówno niepokoje wśród mieszkańców miast, jak i rosnąca fala napięć rewolucyjnych odzwierciedlały coraz większe niezadowolenie z carskiego porządku, a także wzrastającą gotowość do konfrontacji z reżimem i jego przedstawicielami. Nie należy przy tym lekceważyć znaczenia różnych organizacji rewolucyjnych, które przyczyniły się do wzrostu poziomu przemocy, wrażenia nieporządku i poczucia niepewności w Warszawie ${ }^{25}$. Pod koniec 1904 i w 1905 r. działalność rewolucyjna przeniosła się z prywatnych, zakonspirowanych lokali na ulice miast, do parków, na place i w inne miejsca publiczne. Jednocześnie zmianie uległa postawa prezentowana przez różne organizacje polityczne. Działacze PPS-u, SDKPiL-u, Bundu i innych mniejszych ugrupowań przestawali się obawiać przedstawicieli reżimu carskiego, a także innych instytucji panującego porządku społecznego oraz politycznego i coraz śmielej konfrontowali się z nimi ${ }^{26}$. Ponadto należy zauważyć, że podczas gdy uliczni przestępcy

23 „Ha-Jom” (30 sierpnia / 12 września 1906), nr 40, s. 3. Zob. także „Di Naje Cajtung” (29 sierpnia / 11 września 1906), nr 25, s. 2.

${ }^{24}$ Zob. doniesienia w prasie lokalnej na temat zamieszek i niepokojów w Łodzi: Krwawy tydzien, „Kurjer Codzienny” (13/26 czerwca 1905), nr 161, s. 1-2; Krwawe hasta, „Kraj” (1/14 lipca 1905), nr 26, s. 3-6. Na temat rozwoju ruchu robotniczego w Łodzi zob.: Blobaum, Rewolucja ..., s. 87-98.

${ }_{25}$ Zob. wnikliwe omówienie tych kwestii: Neuberger, Hooliganism ..., s. 100-103; Wynn, Workers, Strikes, and Pogroms..., s. 99-108.

${ }_{26}$ Zob. doniesienia o wczesnych starciach między siłami rządowymi a rewolucjonistami pod koniec 1904 r., w tym o wydarzeniach w pobliżu placu Grzybowskiego wywołanych przez grupę rewolucjonistów, którzy „wymachiwali czerwonym sztandarem i śpiewali pieśni rewolucyjne”: Demonstracje w Warszawie, „Kraj” (12/25 listopada 1904), nr 46, s. 5-7; „Kurjer Codzienny" (4/17 listopada 1904), nr 320, s. 1. Zob. także raporty dotyczące wcześniejszych zakłóceń porządku publicznego: Archiwum Główne Akt Dawnych [dalej: AGAD], Prokurator Warszawskiej Izby Sądowej [dalej: PWIS], sygn. 3615, 4 października 1904, nr 7054, s. 4-4v. O rosnącym znaczeniu i śmiałości różnych grup rewolucyjnych pod koniec 1904 i na 
na ogół grozili swoim ofiarom tzw. bronią białą, jak pałki czy noże, organizacje rewolucyjne dysponowały znacznie szerszym i potencjalnie bardziej śmiercionośnym arsenałem środków. W użyciu niejednokrotnie znalazły się rewolwery, materiały wybuchowe i inne rodzaje broni. Znacząco przyczyniło się to do pogorszenia konfliktu oraz do wzrostu przemocy i poczucia zagrożenia, które przenikały życie codzienne w mieście ${ }^{27}$.

Mimo że podstawowe dla omawianego okresu badania zwykle poświęcone są problemom rozwoju myśli rewolucyjnej i organizacji politycznych, należy również zauważyć znaczenie innych zjawisk. W ciągu dyskutowanych lat mianowicie dramatyczna zmiana charakteru i zakresu działalności rewolucyjnej znacząco przyczyniła się do wzrostu poziomu napięcia, lęku i zagrożenia przemocą odczuwanych przez mieszkańców Warszawy, która niejednokrotnie przekształcała się w pole bitwy miejskiej ${ }^{28}$. W istocie łamy gazet wydawanych w języku jidysz i polskim zapełnione były doniesieniami o gwałtownych konfrontacjach zagrażających podstawom funkcjonowania społeczności Warszawy. Przykładem tego może być incydent, do którego doszło w maju 1905 r. na skrzyżowaniu ulic Długiej i Miodowej, kiedy to agenci rządowi próbowali zaaresztować jednego z klientów piekarni Trojanowskiego ${ }^{29}$. Chociaż liczne przykłady działalności rewolucyjnej i zbrojnych starć, do jakich doszło na ulicach Warszawy i innych miast ok. 1905 r., są już znane, chciałbym zwrócić uwagę na procesje publiczne, masowe protesty i gwałtowne starcia, które miały miejsce wiosną tego roku i były powiązane ze śmiercią i pogrzebami kilku działaczy Bundu ${ }^{30}$. Początek tych zdarzeń

początku 1905 r. zob.: Krwawe hasta..., a także: $Z$ departamentu policji: Ruch rewolucyjny w Królestwie Polskiem, „Kurjer Codzienny” (15/28 sierpnia 1905), nr 222, s. 1. Więcej na temat tego zjawiska w: Blobaum, Rewolucja ..., s. 195-201, 217-225.

${ }^{27}$ Zob. więcej szczegółów na temat rodzajów broni wykorzystywanych przez różne grupy rewolucjonistów żydowskich w Warszawie i innych miejscach w tym czasie np. w: AGAD, PWIS, sygn. 3837, 28 sierpnia 1905, nr 1947-1949, s. 11-13v; AGAD, PWIS, sygn. 4160, 25 lipca 1905, nr 1626, s. 48-50v. Zob. także: Blobaum, Rewolucja ..., s. 79, 219, 280-283; „Kraj” (17 lutego / 2 marca 1906), nr 7, s. 10.

${ }^{28}$ Zob. dyskusje naukowe na temat polityki rewolucyjnej w tym czasie: Blobaum, Rewolucja ..., s. 188-233; Tych, Kalabiński, Czwarte powstanie czy pierwsza rewolucja ...; Zimmerman, Poles, Jews, and the Politics of Nationality...

${ }^{29}$ Wybuchy bomby, „Głos” (7/20 maja 1905), nr 20, s. 302. Na temat wysiłków rządu w celu ograniczenia potencjalnych zamieszek związanych z obchodami święta pierwszomajowego w Warszawie w 1905 r. zob. raporty rządowe dotyczące aresztowania żydowskiego krawca Majera Kalmana Raismana na ulicy Gęsiej w: AGAD, PWIS, sygn. 4003, 17 maja 1905, nr 1043, s. 4; o aresztowaniu Joska Sziewy Tigera na ulicy Krochmalnej zob. w: AGAD, PWIS, sygn. 3978, 11 maja 1905, nr 1005, s. 4-4v.

${ }_{30}$ Zob.: Halina Kiepurska, Warszawa w Rewolucji 1905-1907, Warszawa 1974; Waldemar Potkański, Terroryzm na ushugach ugrupowań lewicowych i anarchistycznych $w$ Królestwie Polskim do 1914 roku, Warszawa 2014, s. 135-221. 
wiąże się z datą pogrzebu Izraela Grawiera, działacza Bundu - była to niedziela 2 kwietnia 1905 r. Grawier zmarł dzień wcześniej w więzieniu na Pawiaku. W publicznej procesji upamiętniającej Grawiera uczestniczyły tysiące warszawian - zarówno Żydów, jak i Polaków. Podobnie jak w wielu innych przypadkach kondukt pogrzebowy szybko przerodził się w demonstrację polityczną, której finałem były bójki uliczne pomiędzy demonstrantami a przedstawicielami reżimu. Erupcja wywołanej przez te wydarzenia przemocy doprowadziła do śmierci czterech demonstrantów, którzy zostali zastrzeleni lub ugodzeni bagnetami przez żołnierzy. $\mathrm{Na}$ ulicach Warszawy doszło do gwałtownych starć i krwawych ataków, które przyniosły wiele kolejnych ofiar. ${ }^{31}$

Podobne wydarzenia można odnotować w trakcie całego okresu intensywnego konfliktu między działaczami rewolucyjnymi i przedstawicielami reżimu carskiego, spierającymi się o to, kto ma realną władzę nad Warszawą i sąsiednimi miastami. Wrogie obozy zdawały się czasem bawić w kotka i myszkę, swego rodzaju niebezpieczną zabawę na życie i śmierć, której celem było pozyskanie kontroli nad kształtem i przyszłością miasta. $\mathrm{Na}$ ulicach polskiej stolicy trudno było odnaleźć choćby pozory porządku politycznego i społecznego, a raporty policyjne, akta sądowe i łamy gazet pełne były barwnych opisów szczegółów wielokrotnych starć pomiędzy rewolucjonistami a siłami rządowymi. Kilka tygodni po wyżej opisanych wydarzeniach różne źródła odnotowały szczególnie gwałtowny przypadek konfrontacji między siłami caratu a sympatykami SDKPiL-u. Zdarzenie na jednej z głównych arterii Warszawy, w Alejach Jerozolimskich, zakończyło się śmiercią trzydziestu osób ${ }^{32}$.

W wielu wypadkach prasa lokalna nie ograniczała się jedynie do podania informacji o tego rodzaju konfrontacjach, ale też wzmacniała istniejące już wśród opinii publicznej coraz silniejsze skojarzenia działalności rewolucyjnej z przemocą polityczną, pogłębiając tym samym obawy dotyczące zapaści społecznej i politycznej anarchii. Poniższa relacja $z$ ataku na policjanta z lipca 1906 r., zamieszczona na łamach wydawanego w języku jidysz dziennika „Der Telegraf”, jest dobrym przykładem pewnego rodzaju reportażu na temat przemocy rewolucyjnej. Taki styl konstruowania relacji z wydarzeń

${ }^{31}$ O tym zdarzeniu i powiązanych wypadkach zob.: Ury, Barricades and Banners..., s. 120-126. Zob. także opisy podobnych wydarzeń w Lodzi w czerwcu tego samego roku: Blobaum, Rewolucja..., s. 96-98.

${ }^{32}$ Więcej na temat wydarzeń w Warszawie zob.: AGAD, Kancelaria Generał-Gubernatora Warszawskiego [dalej: KGGW], sygn. 2491, 19 kwietnia / 2 maja 1905. Wcześniej cytowane w: Blobaum, Rewolucja..., s. 91. 
w określony sposób kształtował u wielu czytelników (mieszkańców, przyjezdnych i obserwatorów miasta) obraz społeczności miejskiej. Czytając ten artykuł (jak i wiele innych mu podobnych), trudno było właściwie się zorientować, kto faktycznie nadzorował porządek na warszawskich ulicach. Również nie wiadomo było, do kogo - według prasy - powinno w istocie należeć zadanie kontrolowania przestrzeni miasta:

W piątek o piętnastej trzydzieści pewien policjant jechał tramwajem. Na rogu Marszałkowskiej i Królewskiej pojazd minął wóz z trzema mężczyznami w środku, którzy otworzyli ogień i postrzelili policjanta, po czym uciekli z miejsca [...]. Następnie napastnicy natknęli się na strażnika Mattisa. Ponownie zaczęli strzelać, ranili go i uciekli33.

Do zuchwałych ataków na policjantów i innych przedstawicieli władzy carskiej nie dochodziło wyłącznie w stolicy Królestwa Polskiego. Blobaum zauważa, że na początku 1905 r. PPS oraz inne organizacje rewolucyjne zaczęły prowadzić „kampanię zamachów”, która skierowana była „nie tylko na cele o dużym znaczeniu w sferze publicznej, ale także przeciwko niskim rangą członkom aparatu państwowego" ${ }^{\text {34 }}$.

W takim i innych wypadkach trudno nieraz wyznaczyć granicę pomiędzy przemocą miejską a politycznie motywowanymi czynami skierowanymi przeciwko przedstawicielom władz państwowych. Neuberger ma zatem rację, komentując, że „nigdy nie wiadomo do końca, kto uczestniczył w atakach lub w jakim stopniu były one motywowane względami politycznymi czy też innymi czynnikami”"35. Zatarcie granic pomiędzy zwykłą przestępczością i przemocą typu miejskiego a aktami motywowanymi interesami politycznymi sięgnęło zenitu w $1906 \mathrm{r}$. Wtedy to działania różnych organizacji politycznych coraz częściej zaczęły upodabniać się do pospolitej przestępczości. Do czynów tego typu czasem przyłączali się kryminaliści, którzy w pewnych wypadkach nawet podszywali się pod działaczy politycznych ${ }^{36}$. Szczególnie znaczącym przykładem płynnego

33 „Der Telegraf” (4/17 czerwca 1906), nr 121, s. 3. Zob. o innych doniesieniach na temat przemocy w sferze publicznej, także w tramwajach i pociągach: „Jidiszes Tageblat” (1/14 sierpnia 1906), nr 65, s. 3; „Der Weg” (2/15 kwietnia 1906), nr 75, s. 3.

${ }_{34}$ Blobaum, Rewolucja..., s. 219. Zob. także Neuberger, Hooliganism..., s. 94: „Pod koniec 1905 r. i w szczególności w 1906 r. zbrojne ataki na policjantów stały się powszechne i niebezpieczne". Potwierdzają to także badania Waldemara Potkańskiego - zob. Potkański, Terroryzm..., s. 135-221.

${ }_{35}$ Neuberger, Hooliganism..., s. 95. Zob. opisy tego samego zjawiska w skali lokalnej: AGAD, KGGW, sygn. 2503, 10 września 1905, nr 3203, s. 257-258.

${ }^{36}$ Zob. Blobaum, Rewolucja..., s. 221-223. 
charakteru przemocy i działalności politycznej w tym czasie był tzw. pogrom alfonsów (sutenerów) z maja 1905 r. W ciągu kilku dni w różnych warszawskich domach publicznych doszło do serii konfrontacji pomiędzy przedstawicielami Bundu a członkami przestępczego podziemia żydowskiego $^{37}$. Niezależnie jednak od konkretnych motywacji poszczególnych uczestników tego starcia i innych podobnych wypadków kolejne, otwarte zatargi z przedstawicielami reżimu prowadziły do dalszego zaostrzenia napięć w Warszawie, a także przyczyniły się bezpośrednio do wzrostu poczucia dezorganizacji i strachu w mieście ${ }^{38}$.

Publikowana w języku jidysz gazeta codzienna „Jidiszes Tageblat” wykorzystywała klimat rosnącego przerażenia i voyeurystycznego zainteresowania przemocą, chaosem i anarchią. W celu pokazania wpływu przemocy rewolucyjnej na fatalny stan społeczności miasta oraz wzrost poczucia lęku, które ogarniało wielu mieszkańców Warszawy, dziennik posłużył się danymi statystycznymi. Według poniżej cytowanego i podobnych artykułów Warszawa na początku 1907 r. była nie tylko miastem, w którym nowo przybyli i stali mieszkańcy oraz przyjezdni powinni obawiać się o swoje bezpieczeństwo, ale też miejscem, gdzie nawet uzbrojeni przedstawiciele caratu, czyli siły rządowe przeznaczone do egzekwowania oraz utrzymania porządku społecznego i politycznego, znajdowali się w sytuacji dalekiej do określenia jako „bezpieczna”. Omawiając akty przemocy wobec przedstawicieli reżimu carskiego, dziennik zauważał, że:

W ubiegłym roku, 1906, w Warszawie zginęło dwudziestu wojskowych, siedmiu żandarmów i pięćdziesięciu sześciu policjantów. $Z$ kolei wśród rannych było czterdziestu dwóch wojskowych, dwunastu żandarmów i czterdziestu czterech policjantów. Łącznie - sto siedemdziesiąt dwie osoby. Podłożono dziesięć bomb. W wyniku eksplozji ładunków wybuchowych pięćdziesiąt osób zostało rannych, a osiem zabitych. Okradziono sto czterdzieści dziewięć sklepów monopolowych. W ciągu ostatnich trzech lat osiemdziesięciu trzech policjantów zginęło, a stu dwudziestu czterech zostało rannych ${ }^{39}$.

${ }^{37}$ Zob. np. Pogrom lupanarów, „Kurjer Codzienny” (12/25 maja 1905), nr 130, s. 5-6; Pogrom lupanarów, „Kurjer Codzienny” (13/26 maja 1905), nr 131, s. 5-6; Lynch Warszawski, „Kraj” (20 maja / 2 czerwca 1905), nr 20, s. 9-11. Więcej na temat tych wydarzeń zob.: Ury, Barricades and Banners..., s. 126-129; Aleksandra Jakubczak, „Pogrom alfonsów” $w$ Warszawie 1905 roku w świetle prasy żydowskiej, „Studia Judaica” 18 (2015), nr 2, s. 339-357.

${ }^{38}$ Zob. także omówienie tych problemów w: Neuberger, Hooliganism ..., s. 97, 100-102.

39 „Jidiszes Tageblat” (4/17 stycznia 1907), nr 4, s. 3. Oficjalne dane rządowe za rok 1906 nieco się różnią. Zob.: Oberpolicmajster Piotr Mejer do cara Mikołaja II (Warszawa, 22 grudnia 1907 / 4 stycznia 1908), [w:] Raporty warszawskich oberpolicmajstrów, 1892-1913, red. Halina Kiepurska, Zbigniew Pustuła, Wrocław 1971, nr 14, s. 69. Konkretne przykłady użycia bomb w: AGAD, PWIS, sygn. 4649, 3 listopada 1906, nr 10589, k. 9a-9b. 
W takim i wielu podobnych raportach liczni mieszkańcy Warszawy Żydzi, Polacy i inni - mogli nie tylko przeczytać o powtarzających się starciach między członkami rewolucyjnych organizacji politycznych a przedstawicielami reżimu carskiego, ale także wyobrazić sobie siebie samych jako potencjalne ofiary takich przypadkowych momentów konfrontacji i przemocy, która ogarnęła miasto ${ }^{40}$. Obawy dotyczące przypadkowego charakteru przemocy w Warszawie wzrosły w II połowie 1906 i na początku 1907 r., kiedy to nastąpiła zmiana strategii działania SDKPiL-u, Bundu i innych organizacji, które rozpoczęły praktykę zbrojnych rozbojów. Konfiskaty mienia $\mathrm{z}$ bronią $\mathrm{w}$ ręku pomyślane były tak, żeby zasilić fundusze przeznaczone na broń i inne działania polityczne, ale w rzeczywistości dotyczyły szerokiego spektrum celów, w konsekwencji obejmując zasięgiem oddziaływania przemocy rewolucyjnej znacznie większą liczbę osób ${ }^{41}$. Jesienią 1906 r. tygodnik „Kraj” obliczył, że doszło do co najmniej „siedemdziesięciu trzech różnych ataków lub napadów na kasjerów, tramwaje, sklepy monopolowe i osoby prywatne" w całym imperium ${ }^{42}$. Obawy przed tego rodzaju rabunkami potęgowane były przez wiadomości o gwałtownych - odnotowywanych w Warszawie, Łodzi i innych miejscach - starciach pomiędzy członkami różnych ugrupowań rewolucyjnych ${ }^{43}$. Według obliczeń Blobauma - wyniszczające walki między różnymi grupami na obszarze całego Królestwa przyniosły co najmniej 1000 ofiar ${ }^{44}$. Dla tych mieszkańców Warszawy, którzy nie byli ani zdeklarowanymi rewolucjonistami, ani też nie wykazywali zrozumienia dla spraw, o jakie walczyły grupy rewolucyjne, coraz bardziej konfrontacyjne, gwałtowne i nieprzewidywalne działania różnych organizacji politycznych stały się równie przerażające (a w końcu także odrażające) jak fala przestępczości, już od jakiegoś czasu zagrażająca podstawom funkcjonowania społeczności miejskiej. Jak zauważył Blobaum, „w 1906 r. poparcie dla przemocy politycznej zaczęło słabnąć”45.

40 Więcej o nieregularnym i nieprzewidywalnym charakterze przemocy w tym czasie w: Neuberger, Hooliganism ..., s. 45, 66, 95.

${ }^{41}$ Zob. więcej na temat konfiskat: „Kraj” (17 lutego / 2 marca 1906), nr 7, s. 10; „Kraj” (11/24 maja 1907), nr 14, s. 7; Nahum Nir-Rafalkes, Erszte jorn: In rod fun dor un bawegung, Tel Awiw 1960, s. 139-143; Blobaum, Rewolucja ..., s. 220.

42 „Kraj” (8/21 września 1906), nr 36, s. 9.

${ }^{43} \mathrm{O}$ gwałtownych konfliktach między przedstawicielami różnych partii w tym czasie zob. np.: Terror partyjny, „Przegląd Społeczny” (8 sierpnia 1906), nr 26, s. 313-314; zob. także: Blobaum, Rewolucja..., s. 223-225.

${ }_{44}$ Tamże, s. 224.

45 Tamże, s. 222, 225. Zob. także np.: Warszawa, „Kraj” (1/14 września 1906), nr 35, s. 12. 
Wobec zagrożenia przestępczością miejską oraz zamieszkami na tle rewolucyjnym wielu mieszkańców - zarówno Żydów, jak i Polaków uważało, że poza ucieczką z miasta istnieje niewiele dostępnych im alternatywnych rozwiązań sytuacji. Następujący fragment artykułu z warszawskiego dziennika „Ha-Jom” opisuje poczucie zagrożenia, jakie ogarnęło wielu warszawskich Żydów latem 1906 r., kiedy to nagromadzenie różnych rodzajów przemocy wywołało szczególnie niepokojącą atmosferę i spowodowało wzrost negatywnych nastrojów związanych z lękiem, rozpaczą i paniką:

Po ogłoszeniu przez „Bund” ostatniej proklamacji, wydanej w trzech językach: rosyjskim, polskim i jidysz, strach ponownie ogarnął warszawskich Żydów. Odezwa wzywa Żydów do gotowości, żeby w każdej chwili zareagować na sygnał (podniesiony transparent) i ruszyć na barykady z jakąkolwiek bronią, która wpadnie im w ręce [...]. Ogłoszenie wprawiło wielu spokojnych Żydów w Warszawie w przerażenie. Wielu z nich zdecydowało się na natychmiastową ucieczkę. Inni podążą w ich ślady, kiedy tylko pojawi się „,sygnał”46.

\section{Przemoc ze strony rządu}

Fala rewolucyjnej przemocy z 1905 r. nadal trwała w roku następnym, przy czym zdawało się, że społeczność miasta traci jakiekolwiek pozory organizacji i porządku. Podejmując wysiłki na rzecz opanowania sytuacji w Warszawie i całym regionie, rząd ogłosił stan wojenny ${ }^{47}$. Wydano też instrukcje dla wojska i policji dotyczące działań podczas ewentualnej przemocy wobec Żydów (pogromu) ${ }^{48}$. Wprowadzenie stanu wojennego na ziemiach polskich wywołało trzeci rodzaj przemocy panującej w Warszawie w omawianym czasie, a mianowicie - przemocy ze strony rządu. Dzięki rozszerzonym uprawnieniom, działając ze wzmocnionym wigorem i pod presją strachu przed anarchią, przedstawiciele caratu postanowili stłumić ruchy rewolucyjne, demonstrując siłę i dominację polityczną. Miało to pomóc w przywróceniu poczucia ładu społecznego i politycznego. W ramach rozporządzeń dotyczących stanu wojennego wzmocniono nadzór policji,

46 „Ha-Jom” (23 lipca / 5 sierpnia 1906), nr 7, s. 3. Zob. także: Warszawa, „Kraj” (7/20 lipca 1906), nr 27, s. 11. Opis podobnej sytuacji podczas powstania łódzkiego z 1905 r. w: Blobaum, Rewolucja ..., s. 89, 98.

${ }^{47}$ Opis stanu wojennego na ziemiach polskich - zob.: tamże, s. 260-291.

48 Artur Markowski, Złe sny rosyjskich urzędników. Strach przed pogromami Żydów w Królestwie Polskim i w części zachodnich guberni Imperium Rosyjskiego, „Przegląd Historyczny” 56 (2015), nr 4, s. 749. 
regularnie organizowano blokady dróg, a mieszkańcy miasta podejrzewani o przynależność do ugrupowań rewolucyjnych podlegali rutynowym aresztom i karze więzienia ${ }^{49}$. Częste starcia pomiędzy siłami rządowymi a działaczami rewolucyjnymi jeszcze bardziej uwypuklały fakt, że wielu warszawiaków kwestionowało samą legitymację caratu w odniesieniu do różnego rodzaju prób zapanowania nad Królestwem Polskim ${ }^{50}$. Stan konfrontacji pomiędzy siłami rządowymi a działaczami rewolucyjnymi był szczególnie zaostrzony w Warszawie, gdzie wielu Polaków i Żydów żywiło dużą podejrzliwość lub nawet wrogość wobec rosyjskiego imperialnego aparatu państwowego i jego lokalnych przedstawicieli. Zderzenie wysiłków starającego się zaprowadzić stan wojenny rządu z powszechną niechęcią wobec reżimu carskiego na ziemiach polskich pogłębiło antagonizm między przedstawicielami rządu a lokalnymi mieszkańcami. Zamiast zaprowadzić spokój w społeczeństwie i polityczny porządek działania zaborcy i jego polityka bardzo często powodowały zaostrzenie konfliktów oraz eskalację przemocy i strachu w mieście.

Doniesienia prasy codziennej i innych źródeł z tego okresu dotyczące problemu przemocy ze strony reżimu również dobrze pokazują wpływ, jaki spontaniczne blokady na drogach i przypadkowe aresztowania na ulicach wywierały na panujący wtedy w polskiej stolicy klimat konfrontacji i napięcia. Z upływem czasu wydawało się, iż wcześniejsze nadzieje wielu umiarkowanych zwolenników rewolucji, że na poły demokratyczne reformy z końca 1905 r. spełnią ich oczekiwania, tracą na znaczeniu wobec narastającego poczucia konfliktu ${ }^{51}$. Zamieszczona poniżej nieco prozaiczna relacja z działań władz, opublikowana w 1906 r. na łamach hebrajskojęzycznego dziennika „Ha-Jom”, podkreśla, jaki wpływ na rosnący poziom napięcia w Warszawie miały wysiłki rządu zaborczego na rzecz objęcia kontroli nad miastem:

${ }^{49}$ Zob. przykłady rządowych aresztowań (żydowskich) działaczy rewolucyjnych np. w: AGAD, KGGW, sygn. 2627, 26 stycznia 1906, nr 1049, s. 119-119v; AGAD, KGGW, sygn. 3022, 16 maja 1907, nr 7353, s. 1-7, 15-15v. Na temat intryg związanych ze stanem wojennym w Warszawie zob.: Blobaum, Rewolucja ..., s. 276-279.

${ }^{50}$ Zob. np.: Max Weber, Politics as a Vocation, [w:] tenże, From Max Weber: Essays in Sociology, thum. i red. Hans H. Gerth, C. Wright Mills, London 1948, s. 78 (wyd. pol.: Max Weber, Polityka jako zawód i powołanie, tłum. Andrzej Kopacki, Paweł Dybel, KrakówWarszawa 1998).

${ }^{51}$ Sukcesy liberałów, reformy rządowe i rosnące oczekiwania społeczne w tym czasie - zob.: Abraham Ascher, The Revolution of 1905, t. 1: Russia in Disarray, Stanford 1988, s. 275-303; Terence Emmons, The Formation of Political Parties and the First National Elections in Russia, Cambridge 1983. 
Wczoraj po południu policja i wojsko zablokowały następujące ulice: Franciszkańską, Nowiniarską, Bonifraterską i kilka innych. Dokładnie sprawdzono wszystkie domy położone przy tych ulicach, a osoby, które nie przedstawiły odpowiedniego dokumentu tożsamości lub nie potrafiły udowodnić wykonywanego zawodu, zostały aresztowane ${ }^{52}$.

Mimo że ten konkretny incydent prawdopodobnie nie miał znaczących następstw, inne działania podejmowane przez siły rządowe okazywały się mniej skuteczne, ponieważ osoby podejrzane o działalność rewolucyjną odpowiadały w sposób, który znany im był najlepiej, czyli przemocą. Poniższa relacja z kilku różnych starć, które miały miejsce w pewien sobotni poranek latem 1906 r., pokazuje, jak starania władz zaborczych na rzecz zaprowadzenia porządku bardzo często przynosiły odwrotny skutek i ostatecznie napędzały rosnącą falę zamętu, chaosu i lęku. Cytowany tu przykład (jak i inne wydarzenia tego typu) obrazuje, w jaki sposób oficjalne próby zaprowadzenia kontroli nad miastem często prowadziły do wzmożenia odczucia, że dynamika społeczna miasta wymyka się spod wszelkiej kontroli:

W sobotę o dziesiątej rano, podczas gdy na ulicy Grzybowskiej miejscowy patrol zajmował się przeszukiwaniem przechodniów, kilku mężczyzn otworzyło ogień. Policjant Sidorowicz i żołnierz Fomin zostali postrzeleni, a sprawcy uciekli przez przejście na dziedziniec. Jeden z żołnierzy oddał strzał w kierunku bramy, nie trafiając w nikogo. Godzinę później nadzorca z siódmej dzielnicy, Harasenek, wszedł do domu przy ulicy Wolskiej 8. Kilku mężczyzn wystrzeliło dziesięć razy z rewolwerów, zabijając nadzorcę. Policja zaczęła ich ścigać i [przypadkowo] zastrzeliła przechodzącą tamtędy kobietę $e^{53}$.

\section{Przemoc antyżydowska}

Sprzężenie przemocy miejskiej, działalności rewolucyjnej i działań władz wpłynęło negatywnie na poczucie bezpieczeństwa wielu spośród 775 tys. mieszkańców Warszawy. W wyniku trzech odrębnych fal antyżydowskiej przemocy, które ogarnęły bliższe i dalsze okolice miasta w październiku 1905 r., na wiosnę 1906 i zimą 1907 (w czasach wyborów) oraz latem 1906 r., poczucie osobistego bezpieczeństwa fizycznego u 275 tys. zarejestrowanych

52 „Ha-Jom” (4/17 września 1906), nr 44, s. 4. Dodatkowe przykłady takiej aktywności można znaleźć w: „Di Naje Cajtung” (1/14 sierpnia 1906), nr 1, s. 3. Zob. osobiste relacje autora wspomnień z tego okresu: Nir-Rafalkes, Erszte jorn..., s. 134.

53 „Der Telegraf” (4/17 czerwca 1906), nr 121, s. 3. 
żydowskich mieszkańców miasta uległo dalszej destabilizacji54. Omówione wcześniej zjawiska przemocy miejskiej, rewolucyjnej i tej ze strony władz zaborczych wywierały negatywny wpływ na kondycję Warszawy. Razem z trzema falami przemocy antysemickiej, które dodatkowo wzmogły rosnące poczucie niepokoju, lęku i paniki wśród wielu żydowskich mieszkańców miasta, zjawiska te zmieniły również sposób, w jaki wielu ludzi postrzegało swoją rolę w ówczesnej polityce i społeczeństwie polskim. Mimo że relacje między wymienionymi trzema rodzajami przemocy - miejskiej, rewolucyjnej i zaborczej - z jednej strony a antyżydowskimi atakami z drugiej strony nigdy nie były proste lub bezpośrednie, w łącznym ujęciu wpływ różnych rodzajów przemocy często się kumulował. Ponadto każdy nowy kryzys przyczyniał się stopniowo do rosnącego poczucia braku bezpieczeństwa i przynależności u wielu żydowskich mieszkańców stolicy.

Mimo że przemoc antyżydowska, która wybuchła w październiku 1905 r. w ponad sześciuset różnych miejscowościach południowo-zachodniej części Imperium Rosyjskiego, nie dotarła bezpośrednio do polskich prowincji caratu, Żydzi mieszkający w Warszawie i sąsiednich miejscowościach mieli wówczas pewny, choć ograniczony dostęp do informacji o przyczynach, rodzajach i zakresach pogromów październikowych ${ }^{55}$. Nie ma też żadnego powodu, aby zakładać, iż żydowscy mieszkańcy Warszawy lub innych części ziem polskich mogli przypuszczać, że przemoc ograniczy się wyłącznie do obszarów na wschód od Królestwa Kongresowego lub że władze carskie będą zainteresowane zapewnieniem im ochrony, a nawet zdolne do takiego działania. Należy również zauważyć, że podczas gdy poprzedni wybuch antyżydowskiej przemocy (1881-1882) miał miejsce przede wszystkim na tych samych terenach co pogromy, które wybuchły w 1905 r., fala przemocy z lat 1881-1882 dotarła do polskiej stolicy pod

${ }^{54}$ Zob. przegląd problemów związanych z przemocą antyżydowską u schyłku caratu w: Anti-Jewish Violence: Rethinking the Pogrom in East European History, red. Jonathan Dekel-Chen, David Gaunt, Natan M. Meir, Israel Bartal, Bloomington 2011; Klier, Russians, Jews and the Pogroms of 1881-1882 ...; Pogroms: Anti-Jewish Violence in Modern Russian History, red. John D. Klier, Shlomo Lambroza, Cambridge 1992; Staliūnas, Enemies for a Day...

55 Zob. klasyczne ujęcie tej fali przemocy: Die Judenpogrome in Russland, red. A. Linden [Leo Motzkin], t. 2, Köln-Leipzig 1910. Omówienie przemocy wobec Żydów w 1905 r. w poszczególnych miastach można znaleźć w: Hamm, Kiev..., s. 189-207; Gerald Dennis Surh, The Jews of Ekaterinoslav in 1905 as Seen from Town Hall: Ethnic Relations on an Imperial Frontier, „Ab Imperio” 4 (2003), s. 217-238; tenże, The Role of Civil and Military Commanders during the 1905 Pogroms in Odessa and Kiev, „Jewish Social Studies” 15 (2009), nr 3, s. 39-55; Weinberg, The Revolution of 1905 in Odessa ..., s. 164-187. 
koniec grudnia $1881 \mathrm{r} .{ }^{56} \mathrm{Z}$ tego też powodu koniec 1905 i początek $1906 \mathrm{r}$. były okresem szczególnego napięcia i niepokoju dla wielu mieszkańców Warszawy i okolic. Potwierdzają to różne relacje sporządzone przez urzędników państwowych i innych mieszkańców regionu, które odzwierciedlają zwiększony poziom niepokoju oraz rosnące poczucie niepewności wśród warszawskich Żydów ${ }^{57}$. Dlatego też - chociaż w tym okresie w Warszawie nie odnotowano żadnych większych aktów przemocy wobec Żydów - nie można pominąć problemu postaw, lęków i działań wielu żydowskich (i polskich) mieszkańców Warszawy. Starali się oni zrozumieć zjawisko przemocy antyżydowskiej, która zdawała się wybuchać wokół nich. Przemoc zbiorowa, podobnie jak lęk, który budzi, rzadko przebiega zgodnie z racjonalnymi wzorami zachowań. Stąd też trudności związane z próbą wyjaśnienia obu zjawisk niezależnie od tego, czy próbujemy tego dokonać oddzielnie, czy też łącznie.

Rosnące poczucie strachu podzielane przez wielu Żydów w Warszawie pod koniec 1905 i na początku 1906 r. potęgował powtarzający się widok wielkich demonstracji publicznych, których celem było przyspieszenie daleko idących przemian politycznych i społecznych. Obawy te nie ogarniały wyłącznie mieszkańców żydowskich. Liczne źródła z omawianego okresu - m.in. prasa codzienna - wielokrotnie zajmowały się plotkami (a także ich dostarczały) na temat możliwości wybuchu przemocy antyżydowskiej w Warszawie ${ }^{58}$. Napięcie to doskonale obrazują także akcje ulotkowe podejmowane przez rozmaite (w tym żydowskie) ugrupowania polityczne ${ }^{59}$.

${ }^{56}$ Por. Markowski, Anti-Jewish Pogroms..., s. 227-230; Stanisław Wiech, Społeczeństwo Królestwa Polskiego w oczach carskiej policji politycznej (1866-1896), Kielce 2002, s. 212217; Henryk Bałabuch, Zajścia antyżydowskie w 1881 i 1882 na Lubelszczyźnie w ujęciu władz gubernialnych, „Biuletyn ŻIH” (1993), nr 3-4, s. 22-36.

${ }^{57}$ Należy zauważyć np. telegram ostrzegawczy o pogromach, który został wysłany przez gubernatora generalnego Grigorija Skalona do przedstawicieli rządu w prowincjach w Kaliszu, Kielcach, Łomży, Lublinie, Piotrkowie, Płocku, Radomiu, Suwałkach i Siedlcach w marcu 1906 r.: AGAD, KGGW, sygn. 2650, 21 marca 1906, nr 6394, k. 103.

${ }_{58}$ Zob. przykłady pogłosek o pogromach w tym czasie w: „Der Weg” (8/21 stycznia 1906), nr 7, s. 1; „Jidiszes Tageblat” (14/27 czerwca 1906), nr 25, s. 3. Należy również pamiętać, że pierwszy raport policji dotyczący pogłosek o zbliżającym się w październiku pogromie zbiegł się w czasie z dużą demonstracją endecką 23 października 1905 r. - zob. AGAD, PWIS, sygn. 4364, 24 października 1905, nr 32887, k. 20. O istotnej roli plotek w zamieszkach na tle etnicznym zob.: Paul R. Brass, The Production of Hindu-Muslim Violence in Contemporary India, Seattle 2003, s. 359.

59 Artur Markowski, Okrzyki antypogromowe. Królestwo Polskie przełomu XIX i XX wieku, [w:] Przemoc antyżdowska i konteksty akcji pogromowych na ziemiach polskich $w X X$ wieku, red. Kamil Kijek, Konrad Zieliński, Lublin 2016, s. 65-88. 
Komentując niestabilność sytuacji wynikłej z połączenia protestów publicznych i niepokojów miejskich w regionie Donbasu i Dniepru w tym czasie, Wynn stwierdza, że „każdy protest uliczny mógł łatwo zmienić się w zamieszki lub nawet pogrom" ${ }^{60}$.

Chociaż niepokój panujący wśród społeczności Warszawy do pewnego stopnia przypisać należy narastającym obawom przed ruchami i poglądami rewolucyjnymi, nastroje te często pogarszała widoczna rola różnych tzw. elementów przestępczych $\mathrm{w}$ wielu demonstracjach publicznych i protestach $^{61}$. Pisząc o ówczesnej sytuacji na ziemiach polskich, Blobaum zwraca również uwagę na trudności w rozróżnianiu protestów politycznych i działalności przestępczej ze względu na fakt, że „podczas demonstracji elementy przestępcze wymieszały się z protestującymi”, co dodawało „kolejnego wymiaru rosnącej powszechnej przemocy” ${ }^{2}$. Do podobnych wniosków doszedł Wynn w studium na temat przemocy na tle klasowym i etnicznym w regionie Donbasu i Dniepru; stwierdza on, że:

tłumy składające się głównie z robotników i rzemieślników, wolne - z kilkoma wyjątkami - od pijaków, zgromadziły się w dużych grupach. Policja opisała ich nastrój jako „wrogi” [...]. Widok tak dużych zgromadzeń robotników obudził strach w sercach wielu mieszkańców [...]. Pogłoski o zbliżających się zamieszkach lub pogromie rozeszły się po całym mieście. Na widok demonstracji przerażeni mieszkańcy pozamykali swoje domy i sklepy ${ }^{63}$.

W świetle wyżej opisanych czynników Żydzi, a także nieżydowscy obserwatorzy życia miejskiego odczuwali szczególne zaniepokojenie, kiedy zdawało się, że przybierające na sile publiczne zgromadzenia i demonstracje uliczne zaburzały pozory jakiegokolwiek porządku w Warszawie i innych

${ }^{60}$ Wynn, Workers, Strikes, and Pogroms..., s. 172, 199: „Pogłoski o zbliżających się zamieszkach lub pogromie rozeszły się po mieście. Przerażeni mieszkańcy zamknęli swoje domy i sklepy na widok demonstracji”.

${ }^{61}$ Zob. np.: Warszawa, „Kraj” (7/20 lipca 1906), nr 27, s. 11. Neuberger podobnie stwierdza, że: „Kolejna wielka fala chuligańskiej przemocy rozpoczęła się podczas gwałtownej reakcji na wydanie manifestu październikowego i trwała w ciągu roku 1906, osiągając apogeum latem [...]. W tym okresie, od końca 1905 r. do lata 1906 r. włącznie, atmosfera polityczna przesycona była przemocą i dyskusjami o przemocy" - Neuberger, Hooliganism..., s. 109. Warto odnotować komentarze Tambiaha dotyczące nawracającej roli „bezrobotnych i elementów przestępczych" w zamieszkach etnicznych na wielką skalę w Azji Południowej - zob. Tambiah, Leveling Crowds..., s. 217-218.

${ }^{62}$ Blobaum, Rewolucja..., s. 218. Zob. także Elżbieta Kaczyńska, Ttum a wtadza: Anatomia masowych ruchów w Królestwie Polskim na przetomie XIX i XX wieku, [w:] Przemoc zbiorowa, ruch masowy, rewolucja, red. Elżbieta Kaczyńska, Zbigniew W. Rykowski, Warszawa 1990, s. 67-104.

${ }_{63}$ Wynn, Workers, Strikes, and Pogroms..., s. 172. 
miastach $^{64}$. Odnosząc się do rozmiarów paniki w Warszawie w omawianym czasie, jeden z wewnętrznych raportów rządowych z końca października 1905 r. ostrzegał, że „w dzielnicach żydowskich powtarzają się pogłoski dotyczące przygotowań do pogromów ludności żydowskiej" ${ }^{55}$. Nawiązując do podobnych problemów, inny oficjalny raport z tego okresu donosił, że „wieczorem 30 października ludność żydowską z ulic Ostrowskiej, Miłej i Woleńskiej ogarnął niepokój; młodzież wykrzykiwała, że chuligani będą bić Żydów"66. Przy tej i innych okazjach widmo przemocy antyżydowskiej w sąsiednich regionach, a także widok masowych protestów społecznych w Warszawie wywoływały wzrost obaw o to, że miasto znajduje się na skraju upadku, a stan społecznego i politycznego chaosu może przynieść bezpośrednie zagrożenie żydowskim mieszkańcom miasta ${ }^{67}$.

Jak pokazują wyżej cytowane źródła, zjawisko rosnącego poczucia chaosu i presji strachu przed rychłą zapaścią społeczeństwa nie dotyczyło wyłącznie żydowskich mieszkańców Warszawy. Podobnie jak wielu innych ówczesnych komentatorów organizacje i ugrupowania wrogie warszawskiej społeczności Żydów również miały głęboką świadomość napiętej atmosfery w mieście i coraz bardziej niepewnej sytuacji tej mniejszości. Stąd też w trakcie kampanii wyborczych do I i II Dumy, które odbyły się odpowiednio wiosną 1906 i na początku 1907 r., endecy i organizacje

${ }^{64}$ Zob. np. sprawozdanie dotyczące przemocy antyżydowskiej w miejscowości Ostrów koło Radomia: Pogrom żydów [sic!] w Ostrowie, „Kurjer Codzienny” (21 maja / 3 czerwca 1905), nr 139, s. 2; zob. również artykuły dotyczące pogromu w Żytomierzu w 1905 r.: Zaburzenia, „Kurjer Warszawski” (14 maja 1905), nr 132, s. 8. Zob. także wczesne doniesienia dotyczące pogromów pod koniec 1905 r., np.: Pogrom żydów [sic!], „Kurjer Codzienny” (3 listopada 1905), nr 267, s. 4; Dni „konstytucji i krwi”, „Kraj” (11/24 listopada 1905), nr 43-45, s. 25. Na temat indywidualnego lęku pogromowego na widok zbierającego się thumu por. Markowski, Złe sny..., s. 755.

${ }^{65}$ AGAD, PWIS, sygn. 4364, 29 października 1905, nr 2488, s. 48-49v. Trafną analizę reakcji reżimu na możliwość przemocy wobec Żydów w Królestwie Polskim można znaleźć w rozprawie doktorskiej: Michael Jerry Ochs, St. Petersburg and the Jews of Russian Poland, 1862-1905, Harvard University, 1986, s. 199-237.

${ }^{66}$ AGAD, PWIS, sygn. 4364, 31 października 1905, nr 33383, s. 59. Więcej o korespondencji rządowej i reakcjach na potencjalne wybuchy przemocy antyżydowskiej, a także o doniesieniach nieformalnych żydowskich patroli samoobronnych w Warszawie, uzbrojonych w rewolwery, sierpy i żelazne pręty: tamże, 26 października 1905, nr 33039, s. 25-26; tamże, 27 października 1905, nr 33090, s. 29-29v. Zob. także relację Hertza o strachu i ucieczkach z Lodzi: I. Sh.[Jacob Sholem] Hertz, Di geszichte fun Bund in Lodz, New York 1958, s. 182. Atmosferę tę rejestrowały także ugrupowania polityczne, agitując przeciwko pogromom por. Markowski, Okrzyki..., s. 76.

${ }_{67}$ Zob. o podobnej sytuacji w Odessie: Weinberg, The Revolution of 1905 in Odessa..., s. 15; a także w zapadlisku Donbas-Dniepr: Wynn, Workers, Strikes, and Pogroms..., s. 108109, 127. 
$\mathrm{z}$ nimi powiązane wielokrotnie wykorzystywały rosnące poczucie trwogi u Żydów i powszechnie panujące wrażenie braku ładu społecznego. Zmierzając do popularyzacji zestawu podstawowych antysemickich obrazów, tropów i zagrożeń, ugrupowania nacjonalistyczne posługiwały się strategią manipulacji i zaostrzania napięć pomiędzy grupami. Dlatego też, chociaż zagrożenie przemocą fizyczną oraz bojkot ekonomiczny na ziemiach polskich najczęściej utożsamia się z wyborami do IV Dumy w 1912 r., obie metody - konfrontacji etnicznej i delegitymizacji politycznej - znane już były z kampanii wyborczych do I i II Dumy ${ }^{6}$. Ponadto - mimo że wymienionych tu strategii nie zrealizowano w pełni w tym czasie - wprowadzenie do powszechnego obiegu dyskusji o tego rodzaju zagrożeniach przyczyniło się do umocnienia coraz bardziej napiętego klimatu konfrontacji, jaki panował w Warszawie. Wzmogło to również rosnące poczucie społecznej i politycznej niepewności oraz zagrożenia bezpieczeństwa fizycznego wśród wielu żydowskich mieszkańców miasta. Ponieważ sama groźba ataku jest z natury rzeczy aktem przemocy, więc działania tego rodzaju przyczyniły się do ponownego naruszenia poczucia bezpieczeństwa zarówno pojedynczych osób, jak i całej żydowskiej społeczności Warszawy.

Obawiając się potencjalnych sukcesów wyborczych koalicji zawartej ad hoc między lokalnym żydowskim komitetem wyborczym a polskimi partiami postępowymi w wyborach do dwóch pierwszych Dum w Warszawie, Stronnictwo Narodowo-Demokratyczne i powiązane z nim ugrupowania przeprowadziły kampanie o jawnie antysemickim charakterze. W trakcie tych kampanii wielokrotnie przedstawiano żydowskich mieszkańców miasta jako osoby z natury wrogie czy też jako podejrzaną o nielojalność „piątą kolumnę", której celem jest dominacja, osłabienie i wreszcie zniszczenie polskich aspiracji narodowych ${ }^{69}$. Uparte powtarzanie tego rodzaju strategii retorycznych okazało się niezwykle skutecznym narzędziem wyborczym i pomogło umocnić pewien specyficzny obraz „Żydów” w polskiej polityce na dłuższą część XX w. ${ }^{70}$ Cytowany niżej fragment ulotki kolportowanej w czasie wyborów do I Dumy na początku 1906 r. zwięźle wyraża przykład połączenia ostrzeżenia o zagrożeniu w sferze ekonomicznej z groźbą przemocy fizycznej. Tego typu treści nadawały koloryt i kształt dyskursowi

${ }^{68}$ Zob. o retoryce antyżydowskiej i przebiegu kampanii przed wyborami do Dumy w 1912 r.: Frank Golczewski, Polnische-Jüdische Beziehungen, 1881-1922, Wiesbaden 1981, s. 101-120; Weeks, From Assimilation to Antisemitism ..., s. 163-169.

${ }^{69}$ Zob. dodatkowe informacje na temat tych kampanii: Ury, Barricades and Banners..., s. 214-260; Weeks, From Assimilation to Antisemitism ..., s. 145-147.

${ }^{70}$ Zob. Michlic, Poland's Threatening Other... 
politycznemu. W tym konkretnym przypadku tradycyjny antyżydowski motyw Żyda - wiecznego tułacza, potencjalnie pozbawionego wszelkich znamion lojalności - wykorzystywano, by sportretować „żydów polskich” [sic!'] jako osoby niewdzięczne, jedynie goszczące w Polsce, stanowiące wrogą siłę wewnętrzną, która zagraża jedności i świętości narodu polskiego. Ponadto przy tej okazji (jak i przy innych) zestawiano przykłady tzw. tupetu żydowskiego z groźbami konfliktu ekonomicznego i fizycznego ${ }^{71}$ :

Polska przyjęła Was i osiedliła na swej ziemi wówczas, gdy prześladowano Was [...]. Porzućcie tę niebezpieczną grę, albowiem sami dla siebie sprowadzicie nieszczęście ${ }^{72}$.

Autorzy innej ulotki, rozpowszechnianej w Warszawie w ramach kampanii wyborczej do II Dumy na początku 1907 r., posłużyli się zbliżoną strategią, formułując groźby w sferze działalności ekonomicznej i w zakresie przemocy fizycznej, w celu przeciwdziałania i delegitymizacji żydowskiej działalności politycznej. W tej ulotce wykorzystano również apele do wprowadzenia sankcji gospodarczych i nawiązania do potencjalnych pogromów, które stanowiły nowy etap w dyskursie publicznym dotyczącym aktywności politycznej i praw Żydów w Królestwie Polskim:

Rodacy! Przysięgnijmy!! że jeśli żydzi [sic!] zwyciężą przy wyborach, nie kupimy u żyda [sic!] ani za grosz towaru. Pogromów i praw wyjątkowych nie chcemy, ale... jeśli się nam przeciwstawią, nic na nas nie zarobią i przyjdzie im się z głodu wywędrować i miejsca w Polsce nie zabierać ${ }^{73}$.

Mimo że wybory ${ }^{74}$ do I i II Dumy nie prowadziły bezpośrednio do zorganizowanych bojkotów ekonomicznych lub pogromów antyżydowskich, zarzuty i argumenty tego rodzaju wpłynęły na sposób, w jaki wielu

${ }^{71}$ Na temat motywu Żyda „wiecznego tułacza” zob.: The Wandering Jew: Essays in the Interpretation of a Christian Legend, red. Galit Hasan-Rokem, Alan Dundes, Bloomington 1986.

72 Anonimowa ulotka z kwietnia 1906 r. - Biblioteka Narodowa, Dokumenty Życia Społecznego, sygn. Ii 1e, nr 2916; przywołana ulotka cytowana jest również w: Zimmerman, Poles, Jews, and the Politics of Nationality..., s. 217.

${ }_{73}$ Anonimowa ulotka z lutego 1907 r. - Archiwum Akt Nowych, Archiwum Polskiej Partii Socjalistycznej, 305/III/45, teczka 3, k. 44. Groźbę pogromów wykorzystywano w bardzo pragmatyczny sposób zarówno wśród prawicy, jak i lewicy - por. Markowski, Okrzyki..., s. $85-86$.

${ }^{74} \mathrm{O}$ wadze tego zagadnienia dla relacji polsko-żydowskich por. Grzegorz Krzywiec, Żydzi, „kwestia żydowska” $i$ antysemityzm na ziemiach polskich $w$ kontekście środkowoeuropejskim na przetomie XIX $i$ XX wieku: Antysemicki habitus - kod antysemicki-ideologia antysemicka, [w:] Drogi odrębne, drogi wspólne. Problem specyfiki rozwoju historycznego Europy Środkowo-Wschodniej w XIX-XX wieku, red. Maciej Janowski, Warszawa 2014, s. 295. 
żydowskich mieszkańców Warszawy postrzegało swoją sytuację i miejsce w społeczeństwie polskim. Groźby sankcji ekonomicznych i przemocy fizycznej stanowiły przede wszystkim przejście od tradycyjnych zarzutów pod adresem Żydów i powiązanej z nimi retoryki do ich wprowadzenia i instrumentalizacji w sferze politycznej, coraz bardziej nastawionej na konfrontację $e^{75}$. Weeks i inni badacze wskazują zatem wybory do wczesnych Dum jako kluczowe punkty zwrotne w historii stosunków między Polakami i Żydami ${ }^{76}$.

Zagrożenia restrykcjami w sferze gospodarczej i przemocą fizyczną nie prowadziły bezpośrednio do wybuchów masowych aktów agresji. Jednakże podzielane przez wielu Żydów narastające oczekiwanie międzygrupowej konfrontacji i towarzyszące temu poczucie zagrożenia bezpieczeństwa fizycznego uległy dalszemu pogłębieniu latem 1906 r. Stało się tak za sprawą dwóch szczególnie brutalnych pogromów, do których doszło w nieodległych od Warszawy miastach, zamieszkanych przez znaczący odsetek ludności etnicznie polskiej. Pierwszy pogrom nastąpił w Białymstoku w czerwcu 1906 r., drugi zaś około trzech miesięcy później w centrum Siedlec ${ }^{77}$.

Komentowane szeroko przez prasę w języku polskim, jidysz i hebrajskim pogromy w Białymstoku i Siedlcach spotkały się z potępieniem ze strony całej polskiej sceny politycznej. Wydarzenia te potwierdziły najgłębsze

75 Więcej na temat konfliktu etnicznego w dobie demokratyzacji, mobilizacji etnicznej i napięć pomiędzy różnymi grupami w: Ward Berenschot, Riot Politics: Hindu-Muslim Violence and the Indian State, London 2011, s. 7-11; Tambiah, Leveling Crowds..., s. 214, 228, 299; Steven I. Wilkinson, Votes and Violence: Electoral Competition and Ethnic Riots in India, Cambridge 2004.

${ }^{76}$ Więcej na temat lat 1905-1907 jako punktu zwrotnego w stosunkach polsko-żydowskich w: Weeks, From Assimilation to Antisemitism ..., s. 129-165; Ury, Barricades and Banners..., s. 214-260.

${ }^{77} \mathrm{O}$ pogromie w Białymstoku zob. Artur Markowski, Pogromy, zajścia, ekscesy. Zbiorowe akty przemocy przeciw Żydom w Bialymstoku pierwszych dekad XX wieku, „Studia Judaica” 14 (2011), nr 1, s. 23-44; tenże, Raznyje istorii. Bietostockij pogrom 1906 g. w fotografijach, [w:] Trudy po jewriejskoj istorii i kulturie. Matieriaty XXI Mieżdunarodnoj jeżegodnoj konfieriencyi po judaikie, red. Leonid F. Kacis et al., Moskwa 2014, s. 115-126; Paweł Korzec, Pót wieku dziejów ruchu rewolucyjnego Białostocczyzny (1864-1914), Warszawa 1965, s. 259-280; M. I.[Moissaye J.] Olgin, 1905, New York 1940, s. 152-180. Zob. także: AGAD, KGGW, sygn. 2635, 15 czerwca 1906, nr 829, s. 357-358v; tamże, 12 czerwca 1906, nr 1105, s. 359-361. Szczegółowe relacje z wydarzeń w Siedlcach w: Stanisław Martynowski, Pogrom w Siedlcach, Łódź 1936; Józef Bekker, The Day after the Pogrom: A Documentary Account, „Polin” 13 (2000), s. 347-365; Markowski, Anti-Jewish Pogroms..., s. 230-233; Szymon Rudnicki, Pogrom siedlecki, „Kwartalnik Historii Żydów” (2010), nr 1, s. 18-39. Zob. także oficjalny raport o pogromie w Siedlcach przedrukowany w: Matieriaty $k$ istorii russkoj kontr-riewolucyi. Pogromy po officialnym dokumientam, t. 1, St. Petersburg 1908, s. 405-412. 
obawy wielu żydowskich mieszkańców Warszawy i całego regionu ${ }^{78}$. Lata niepokojów, przemocy politycznej, represji ze strony władz i antysemickiej retoryki wyborczej zawładnęły porządkiem społecznym i politycznym w Warszawie, co zagroziło poczuciu przynależności i bezpieczeństwa, które wielu Żydów z trudem osiągnęło. Latem 1906 r. wśród warszawskiej ludności żydowskiej nadal krążyły niepokojące pogłoski; pogłębiał się też strach i niepokój związany z wpływem, jaki przestępczość miejska, konflikty polityczne, represje ze strony władz oraz utarczki związane $\mathrm{z}$ wyborami mogą mieć na jej losy ${ }^{79}$. Jak zauważył wydawany w języku polskim tygodnik „Kraj”, w lipcu 1906 r. atmosfera w Warszawie stała się rzeczywiście napięta:

Tydzień ubiegły zaznaczył się przede wszystkiem panicznym strachem przed pogromem. W całem mieście, a zwłaszcza w dzielnicy żydowskiej, powtarzano przez dni kilka na rozmaite tony: „Będzie pogrom! Będzie pogrom!...” ${ }^{80}$

Wiele z powszechnie krążących pogłosek i towarzyszących im momentów kryzysowych okazało się jedynie krótkotrwałymi epizodami zbiorowej paniki. Mimo to powtarzający się cykl - który można by nawet określić jako rytuał zbiorowy - plotek, poczucia zagrożenia i obaw przed antyżydowskimi wybuchami agresji sprawił, że pogromy w Białymstoku i Siedlcach latem i jesienią 1906 r. postrzegano jako jaskrawy przykład tego, co potencjalnie może się wydarzyć również w Warszawie (lub jakimkolwiek innym mieście). Widziano możliwość całkowitego załamania wcześniej istniejących stosunków społecznych, zupełnego niepowodzenia wysiłków władz na rzecz utrzymania porządku czy nawet pozorów dobrze funkcjonującej społeczności miejskiej. Wyobrażano sobie, że w wyniku takiego

78 Zob. więcej na temat tych pogromów i atmosfery latem 1906 r. w: Ury, Barricades and Banners..., s. 263-267. Prasa całego świata donosiła o pogromie w Białymstoku, często codziennie relacjonując nowe wydarzenia. Chciałbym podziękować Robertowi Blobaumowi za jego wnikliwe uwagi na temat znaczenia tych wydarzeń. Doniesienia o pogromie w Białymstoku w polskiej prasie - zob. np.: Ohydna zbrodnia, „Kurjer Warszawski” (16 maja 1906), nr 164, s. 1; W Biatymstoku, „Tygodnik Ilustrowany” (23 czerwca 1906), nr 25, s. 485-486. Zob. także doniesienia na temat przemocy wobec Żydów w Siedlcach: Wypadki w Siedlcach, „Kurjer Warszawski” (12 września 1906), nr 252, s. 8; Krwawe dni Siedlec, „Tygodnik Ilustrowany” (22 września 1906), nr 38, s. 746-747. Część z nich omówiona jest w: Adam C. Dobroński, Pogrom białostocki 1906 w świetle prasy polskiej, „Białostocczyzna" (1991), nr 4, s. 13-16.

79 Warto odnotować obawy urzędników państwowych dotyczące potencjalnych ognisk przemocy antyżydowskiej w sąsiednim Otwocku w sierpniu 1906 r. - zob. AGAD, KGGW, sygn. 2632, (?) sierpnia 1906, nr 1276, s. 32-33v; tamże, 7 sierpnia 1906, nr 5697/1, s. 34.

80 Warszawa, „Kraj” (7/20 lipca 1906), nr 27, s. 11. 
obrotu spraw ludność żydowska znajdzie się w szczególnie trudnej sytuacji - będzie narażona na atak i bezbronna. W owym kilkuletnim okresie oddziaływania różnych form przemocy, długotrwałego lęku i konkretnych wypadków niepewności co do własnej egzystencji społeczność żydowska Warszawy i okolicznych miast, jak również jej kultura i życie polityczne zostały swoiście naznaczone i przekształcone w sposób zupełnie fundamentalny. Dodatkowo - czas rewolucji wytworzył wręcz namacalny (można go nawet nazwać realistycznym) strach przed antyżydowską przemocą.

\section{Wnioski: przemoc, strach i lęk przed przemocą}

Doświadczenia Żydów (i Polaków) w Warszawie podczas rewolucji 1905 r. pokazują, że poziomu napięcia między grupami i roli przemocy etnicznej nie można zmierzyć jedynie poprzez skoncentrowanie się na antyżydowskich atakach i ich często tragicznych skutkach oraz poprzez udokumentowanie tych incydentów. Przeciwnie - takie i łączące się z nimi wydarzenia najlepiej zbadać i zrozumieć w ramach szerszego zbioru odrębnych, lecz powiązanych zjawisk społecznych i politycznych, które wielokrotnie zazębiają się i wpływają na siebie, zmieniając życie Żydów warszawskich w dogłębny, czasem niewymierny sposób ${ }^{81}$. Korzyści, jakie przynosi zastosowanie kontekstowego i synchronicznego podejścia do badania antyżydowskich postaw i przemocy, nie tylko ukazują niedociągnięcia szkoły „długiego trwania” w studiach nad antysemityzmem, ale także eksponują ograniczenia właściwe upolitycznionym interpretacjom, których celem jest przedstawienie stosunków polsko-żydowskich w wyłącznie pozytywnym świetle. Najważniejsze jest jednak to, że badanie różnych form przemocy, które jednocześnie zakłócały i przedefiniowywały życie codzienne we wczesnym okresie XX-wiecznej Warszawy, pokazuje, jak ogromne znaczenie ma analiza konkretnych kontekstów społecznych, politycznych i historycznych dla naukowców chcących lepiej zrozumieć zarówno historię Żydów, jak również długą i trudną drogę stosunków polsko-żydowskich. Badacze, którzy przyjmują jednowymiarowe wyjaśnienie przyczyn konfliktu etnicznego i przemocy w stolicy, ryzykują, że przy tym założeniu powstanie błędna interpretacja poziomu przemocy, napięcia i strachu w mieście. Taka

${ }^{81}$ Więcej na ten temat w: Donald Bloxham, Martin Conway, Robert Gerwarth, A. Dirk Moses, Klaus Weinhauer, Europe in the World: Systems and Cultures of Violence, [w:] Political Violence in Twentieth-Century Europe, red. Donald Bloxham, Robert Gerwarth, Cambridge 2011, s. 11-39, zwłaszcza s. 19. 
postawa badawcza może również prowadzić do niezrozumienia wpływu, jaki te odrębne, lecz zarazem powiązane ze sobą formy przemocy miały nie tylko na siebie nawzajem, ale także na samą społeczność żydowską oraz na obraz i miejsce Żydów w polskiej polityce przez większą część $\mathrm{XX}$ w. ${ }^{82}$ Naukowe i publiczne debaty w kręgach akademickich i poza nimi, dotyczące cech charakterystycznych przemocy antyżydowskiej, podkreślają ważność stanowiska Brassa co do następującej po zakończeniu agresji „walki o kontrolę znaczenia zamieszek" ${ }^{83}$.

Dlatego też, chociaż ostatecznie w latach 1904-1907 w Warszawie nie doszło do starć na tle etnicznym lub pogromów antyżydowskich, długotrwałe oddziaływanie różnych rodzajów przemocy - miejskiej, politycznej, antysemickiej oraz ze strony władz carskich - doprowadziło do tego, iż wielu Żydów nie tylko obawiało się ewentualnych gwałtownych wybuchów agresji, ale też zmieniało swoje postępowanie pod wpływem tych lęków ${ }^{84}$. Niektóre osoby reagowały ostrą awersją zarówno do zwykłej, jak i rewolucyjnej działalności politycznej, a później całkowicie odcinały się od sfery publicznej, powracając do spraw społecznych, politycznych i gminnych społeczności żydowskiej. Mimo że po wprowadzeniu stanu wojennego nastąpił spadek lub załamanie aktywności politycznej w całym społeczeństwie polskim, objawy i skutki tego zjawiska były znacznie ostrzejsze i bardziej dalekosiężne wśród warszawskich Żydów ${ }^{85}$. Niektórzy komentatorzy życia społecznego i politycznego twierdzili nawet, że dla wielu żydowskich mieszkańców Warszawy trzeba by było upływu niemal stu lat, żeby mogli znów poczuć się komfortowo, zajmując otwarte - nie mówiąc już o postawie kontestacji - stanowisko jako $\dot{Z} y d z i$ w polskiej sferze politycznej. Dlatego też, chociaż w tym okresie w Warszawie nie doszło do działań antyżydowskich na dużą skalę czy pogromów, otwarcie antysemickie kampanie wyborcze endecji, jak również powtarzające się widmo przemocy antyżydowskiej w nieodległych miastach, jak Białystok i Siedlce, ostatecznie osiągnęły swój cel - odstraszenia Żydów mieszka-

${ }_{82}$ Zob. więcej na temat różnych interpretacji przemocy masowej: Brass, The Production of Hindu-Muslim Violence..., s. 380.

83 Tamże, s. 24.

${ }^{84}$ Komentarze Stein dotyczące pogromu w Warszawie pod koniec 1905 r. są błędne zob. Sarah Abrevaya Stein, Making Jews Modern: The Yiddish and Ladino Press in the Russian and Ottoman Empires, Bloomington 2004, s. 109-110. Pisze o tym Markowski w: Artur Markowski, Sprawcy, ofiary, świadkowie. Fotografie pogromów Żydów w Imperium Rosyjskim 1903-1906, „Przegląd Historyczny” 54 (2013), nr 1, s. 7.

${ }^{85}$ Procesy te w szerszym aspekcie omówione są szczegółowo w: Blobaum, Rewolucja..., s. $286-289$. 
jących w stolicy i regionie od udziału w życiu politycznym, o działalności rewolucyjnej nawet nie wspominając. Podobnie jak w Paryżu, Wiedniu i innych głównych ośrodkach życia w Europie połączenie zaciekłego antysemityzmu politycznego i groźby przemocy antyżydowskiej miało równie przytłaczające (może również tak samo skuteczne) działanie w Warszawie na przełomie XIX i XX w. jak szeroko rozpowszechniona przemoc antyżydowska na terytoriach na wschód od Królestwa Polskiego ${ }^{86}$. Wpływ tych zmian na charakter społeczności i kultury żydowskiej, a także przebieg stosunków polsko-żydowskich w Warszawie w pozostałych latach XX w. pozostanie przedmiotem dalszych badań.

Z języka angielskiego przetożyła Anna Switzer

Scott Ury Uniwersytet w Tel Awiwie scottury@post.tau.ac.il

${ }^{86} \mathrm{O}$ wpływie afery Dreyfusa na społeczność żydowską w Paryżu i we Francji w tym czasie zob.: Michael Marrus, The Politics of Assimilation: The French Jewish Community at the Time of the Dreyfus Affair, Oxford 1980; Ruth Harris, Dreyfus: Politics, Emotion, and the Scandal of the Century, New York 2011. Na temat początków politycznego antysemityzmu w Wiedniu na przełomie wieków zob.: John W. Boyer, Political Radicalism in Late Imperial Vienna: Origins of the Christian Social Movement, 1848-1897, Chicago 1981; Carl E. Schorske, Fin-de-Siècle Vienna: Politics and Culture, New York 1981; Robert S. Wistrich, The Jews of Vienna in the Age of Franz Joseph, Oxford 1989, s. 205-237. 